\title{
PERFORMANCE ASSESSMENT OF A TYPICAL SEMI ARID WATER RESERVOIR FOR DIFFERENT KINDS OF OPERATIONS
}

\author{
C J Jagadeesha ${ }^{1}$, J Brema ${ }^{2}$, E J James ${ }^{3}$ \\ ${ }^{1}$ Former Scientist / Engineer ISRO \& \\ Department of Civil Engineering, Karunya Institute of Technology and Sciences, \\ Coimbatore, Tamilnadu, India \\ ${ }^{2}$ Professor, Department of Civil Engineering, Karunya Institute of Technology and Sciences, \\ Coimbatore, Tamilnadu, India \\ ${ }^{3}$ Emeritus Professor, Water Institute, Karunya Institute of Technology and Sciences, \\ Coimbatore, Tamilnadu, India
}

\begin{abstract}
The reservoir operations play an important role in conserving water. However reservoir operations go adhoc, many a times, for dealing with pressing socio-political needs of upstream or downstream users. There are many reservoirs in Indian geography where there are no consistent reservoir operation rules which are practiced. The existing way of operations practiced in the field, standard operating policies projected by water resources engineers, and new policies like hedging operations suggested by specialists need to be compared with appropriate performance criteria so that water conservation can be understood by field engineers. This has been simulated for a semiarid reservoir and several parameters of performance were applied suggesting where, when and how long one can hedge the water release for future use in an irrigation /water year. The flexible and feasible reservoir water releases using hedging can be employed.
\end{abstract}

Keywords: actual operations, hedging, optimisation, performance indicators, simulation, standard operating policy

Cite this Article: C J Jagadeesha, J Brema and E J James, Performance Assessment of a Typical Semi Arid Water Reservoir for Different Kinds of Operations, International Journal of Civil Engineering and Technology (IJCIET), 12(7), 2021, pp. 20-30. https://iaeme.com/Home/issue/IJCIET?Volume $=12 \&$ Issue $=7$

\section{INTRODUCTION}

The use of rule curves for the operation of reservoirs is an age old practice. However, unless properly used, rule curves can result in high, single period water shortages (or vulnerability) even when the overall volumetric reliability remains acceptable. The reservoir operation optimization has been suggested as one of the best solutions for meeting increasing water 
demands in the last decades. Reservoir operation is a sequential process. Operation decisions in preceding periods affect water availability in subsequent periods, and future stream flow conditions affect current decision making.

The application of hedging rules in reservoir operation is one of the important advances in the field of reservoir operation studies during the past three decades. Plenty of research has been done on this subject of obtaining the optimal operating policy for single and multi-reservoirs serving single or multiple purposes, over the last four decades and detailed literature reviews have been provided by Yeh [1], Labade [2], Draper [3] and Wurbs [4] in which various mathematical programming formulations and solution techniques have been discussed in detail. The various reservoir hedging rules proposed in the water resources management literature are also examined for their implications, advantages and limitations and review of few recent analytical studies as well as optimal hedging operation based studies that deal with reservoir hedging; and providing future research directions are available [5]. One of the critical questions for hedging research is how long the forecast period should be so that reliable inflow forecast in the period can be used for decision making under hedging.[6] . This paper expands a theoretical analysis presented by Draper and Lund [2004] and develops a conceptual two period model for reservoir operation with hedging that includes future reservoir inflow explicitly [7].

The engineers in charge of reservoir operations (mostly for irrigation dominated supply uses from water reservoir) in India, generally use such rules for operations, many a times there are no records of these. They are mostly based on water demands which are fixed in the beginning of the irrigation season by crop estimates provided by village panchayats and fixed demand scenario for drinking water needs based on population. The crop water demands are assessed based on duty / delta concepts of engineers as provided in irrigation commission (1972) reports for protective irrigation. Many a times when crop water demands from tail end areas of both main canals as well as each distributary are projected to engineers through protests / demonstrations by farmers, as there is no online communication strategies prevalent in command areas in general ; the decisions on reservoir and canal operations are taken in crisis mode in an adhoc way. Interest groups, socially and politically, also influence decision making of irrigation engineers for reservoir operations. This we call it as actual operation's policy (AOP). There are some academic studies at high end water reservoir operations using stochastic dynamic programming, linear programming, game theory, genetic algorithms, neural networks etc., , which are done by academic experts in union with irrigation engineers data, sometimes; and these are not recorded in operational work books of engineers. The actual operation's policy (AOP) of all reservoirs needs attention to assess present performance of the reservoir. Apart from this, how best other release policies like standard operating policy (SOP), hedging rule, linear decision rule (LDR), $\delta$-release policy [8] make reservoirs perform better/ best / not so good needs to be understood.

In this study standard operating policy is simulated for reservoir operation under a fixed water delivery target. SOP releases water as close to the delivery target as possible, saving only surplus water for future delivery. When the objective of reservoir operation is to minimise the expected value of deficit over the decision horizon or any other linear function of deficit, SOP is the optimal operating policy. SOP is practical during periods of operation when inflow is plentiful. However, it neglects considering potential shortage vulnerability during later periods. The consideration of hedging policy for reservoir operations is demonstrated for KRS reservoir, with starting water availability and ending water availability considerations, to arrive at performance indicators useful for reservoirs in semi-arid region, in general. 


\section{THE STANDARD OPERATING POLICY (SOP) AND HEDGING POLICY}

The existing SOP used for water supply is presented in Fig.1 [9]. The X-axis is representing available water and the $y$-axis is representing the sum of release and spill. D is the demand and $\mathrm{K}$ is the capacity of the reservoir. The available water is defined as the sum of beginning storage in the reservoir and the inflow during the period minus the evaporation loss during the period. In this case, demand is constant and if the available water is less than demand all the available water is released. At the point $\mathrm{P}_{1}\left(\mathrm{P}_{1 \mathrm{x}}, \mathrm{P}_{1 \mathrm{y}}\right)$ the available water is equal to the demand and at $\mathrm{P}_{2}$ $\left(\mathrm{P}_{2 \mathrm{x}}, 2 \mathrm{y}\right)$, the available water is sum of capacity of the reservoir and the demand. If the available storage is between $\mathrm{P}_{1 \mathrm{x}}$ and $\mathrm{P}_{2 \mathrm{x}}$, the release is equal to demand. The line between $\mathrm{P}_{0}$ and $\mathrm{P}_{1}$ makes an angle of $45^{\circ}$ with the horizontal.

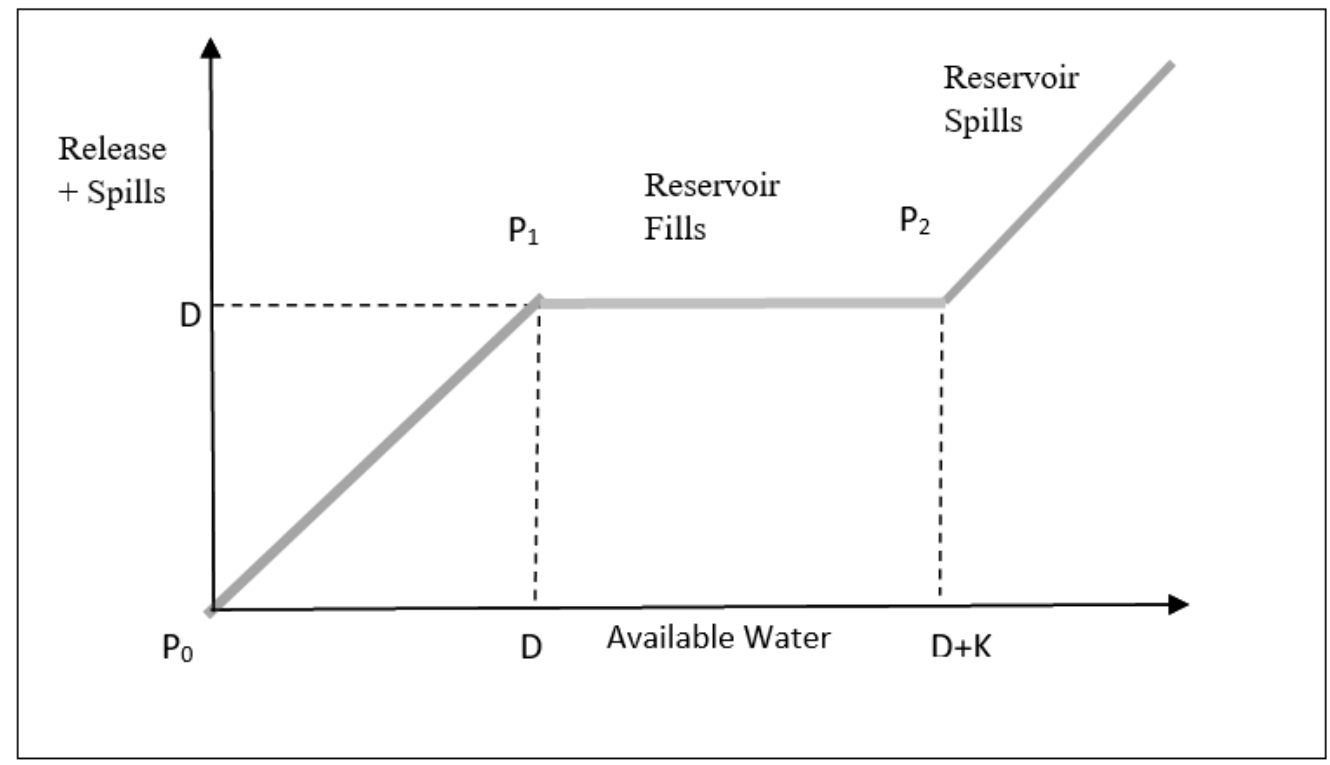

Figure 1 Standard Operating Policy for a Water Supply Reservoir

The SOP (a) delivers the target demand if water is available,(b) retains extra water in storage before reservoir is full, and (3) spills when capacity is exceeded, as plotted in Figure1. SOP provides the optimal solution to a dynamic reservoir operation problem if the objective is to minimise the total release shortfall.

In order to use and plot hedge rule of reservoir operations Fig.1 needs to be modified. See Fig.2. The releases / delivery should be non-negative $(\mathrm{D} \geq 0)$ and less or equal to current water available $(\mathrm{D} \leq \mathrm{A})$. Also, the upper bound of delivery should not exceed demand $\mathrm{D}_{\mathrm{m}}$. Hence now we can write the overall condition as: $\mathrm{D} €\left[0, \min \left(A, D_{m}\right)\right]$. Refer Fig. 2 which shows these constraints. In addition, the release under the hedging rule is less than the SOP (the level of current demand). See Fig.3. Hedging starts from the "critical point" ( $\left.\mathrm{D}_{0} \mathrm{~A}_{0}\right)$, which is also marked as the point of "starting water availability" (SWA) and ends with the point of "ending water availability" (EWA). In this section water is "shared" between release for current demand and storage for future demand following the hedging rule. When the current water availability is too small (less than the critical availability or $\mathrm{A}_{0}$ or SWA) or too large (greater than EWA), there is no need for hedging and reservoir operation follows SOP. 


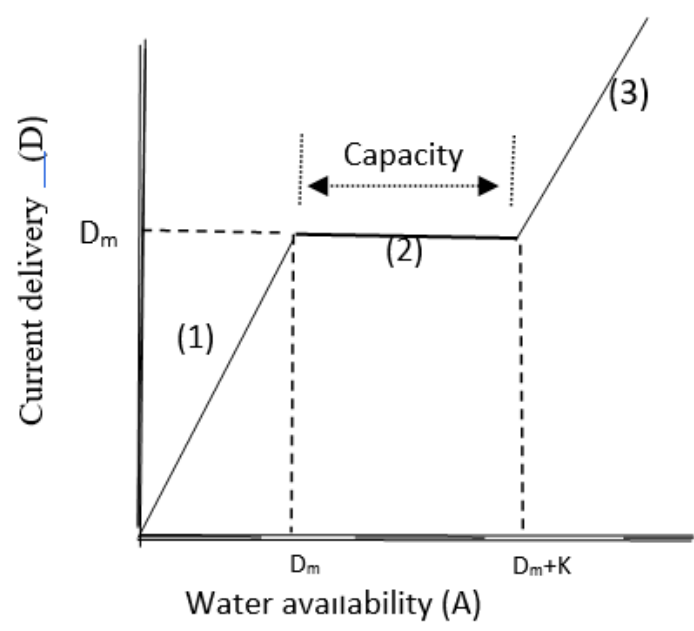

Figure 2 Constraints Defined

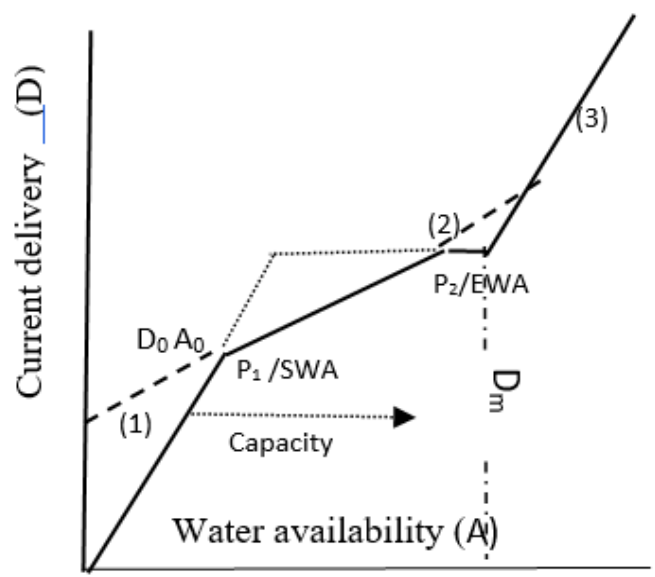

Figure 3 Hedging Rule Graphic

\section{THE SIMULATION OF SOP AND ITS COMPARISON WITH ACTUAL OPERATIONS FOR A SEMI-ARID KRS RESERVOIR}

Krishna Raja Sagar dam is constructed across main Cauvery in Karnataka, India and water reservoir is called as Krishna Raja Sagar (KRS) Reservoir. KRS has the water spread area of 103.99 Million $\mathrm{m}^{2}$ at $752.489 \mathrm{~m}$ reduced level (above mean sea level) and having a capacity of 1400 Million $\mathrm{m}^{3}$.KRS is in the Cauvery basin. In the Cauvery basin, four distinct seasons occur. They are winter, summer, south-west monsoon, and north-east monsoon season in this basin. In Cauvery basin there are few completed and ongoing major irrigation projects. Cauvery delta major irrigation project, Hemavathi major irrigation project, Cauvery Mettur major irrigation project, Parambikulam Aliyar major irrigation project, Krishnaraj Sagar major irrigation project and Harangi major irrigation project which is an ongoing project are those major projects having considerable command area falling within the Cauvery Basin. In the downstream Tamilnadu state, immediately below KRS, Cauvery Mettur Major Irrigation project is an important project of Tamil Nadu with some related structure like grand anicut and Mettur dam associated to it. It provides an ultimate irrigation potential of 111.70 thousand ha and covering a cultivable command area of 103.60 thousand ha benefitting the districts of Thanjavur, Pudukkottai. [10]

The Cauvery delta major irrigation project falling in the basins of Cauvery and east flowing region from Pennar to Kanyakumari has an ultimate irrigation potential of 504.64 thousand ha and a largest cultivable command area of 368 th ha in this basin assisting large area of irrigation in the districts of Thanjavur and Karaikal. The above description of study area with KRS and downstream reservoir - canal fed irrigation systems clearly puts lot of stress in the management of KRS water reservoir operations. Hence to rationalise the water releases from KRS the reservoir operation procedures are simulated and compared with actual operations.

The reservoir operation is simulated as per Fig. 1 for understanding standard operating policy on Krishna Raja Sagar Reservoir. Refer TABLE 1. The actual inflows are used instead of forecasted ones, as the data was available only for fifteen years which is too less for forecasting. Derive TABLE 2 
C J Jagadeesha, J Brema and E J James

Table 1 KRS Storages and Releases as per SOP Rule 1995-96

Project Water Demands (PD)

\begin{tabular}{|c|c|c|c|c|c|c|c|}
\hline Months & $\begin{array}{c}\text { Storage } \\
\text { at } \\
\text { the begin } \\
\text { as per } \\
\text { SOP } \\
(\mathbf{S t} \text { soP })\end{array}$ & $\begin{array}{c}\text { Inflow } \\
\text { During } \\
\text { period } \\
\mathbf{t}\left(\mathbf{I}_{\mathbf{t}}\right)\end{array}$ & $\begin{array}{c}\text { Evaporation } \\
\text { During } \\
\mathbf{t}\left(\mathbf{E}_{\mathbf{t}}\right)\end{array}$ & $\begin{array}{c}\text { Project } \\
\text { Water } \\
\text { Demand } \\
\text { during } \mathbf{t} \\
\left(\mathbf{D}_{\mathbf{t}}\right)\end{array}$ & $\begin{array}{c}\text { Releases } \\
\text { as per } \\
\mathbf{S O P} \text { in } \\
\mathbf{t}\left(\mathbf{R t}_{\text {sop }}\right)\end{array}$ & $\begin{array}{c}\text { Spill or } \\
\text { overflow } \\
\mathbf{d u r i n g} \\
\mathbf{t}\left(\mathbf{O}_{\mathbf{t}}\right)\end{array}$ & $\begin{array}{c}\text { Reservoir } \\
\text { Storage } \\
\text { at the } \\
\text { end of } \\
\mathbf{t}\left(\mathbf{S}_{\mathbf{t})}\right)\end{array}$ \\
\hline & & & & & & 254 \\
\hline Jun & 254 & 95 & 4 & 389 & 345 & 0 & 0 \\
\hline Jul & 0 & 843 & 14 & 295 & 295 & 0 & 534 \\
\hline Aug & 534 & 401 & 15 & 181 & 181 & 0 & 739 \\
\hline Sep & 739 & 903 & 13 & 190 & 190 & 39 & 1400 \\
\hline Oct & 1400 & 206 & 12 & 290 & 290 & 0 & 1304 \\
\hline Nov & 1304 & 160 & 12 & 190 & 190 & 0 & 1262 \\
\hline Dec & 1262 & 94 & 11 & 326 & 326 & 0 & 1019 \\
\hline Jan & 1019 & 65 & 11 & 240 & 240 & 0 & 833 \\
\hline Feb & 833 & 10 & 10 & 201 & 201 & 0 & 632 \\
\hline Mar & 632 & 16 & 10 & 363 & 363 & 0 & 275 \\
\hline Apr & 275 & 19 & 6 & 364 & 288 & 0 & 0 \\
\hline May & 0 & 5 & 6 & 363 & 1 & 0 & 0 \\
\hline
\end{tabular}

Table 2 Derived from KRS SOP Operations 1995-96 PD

\begin{tabular}{|c|c|c|c|}
\hline Months & $\mathrm{D}$ & $\mathrm{R}_{\mathrm{t} \text { SOP }}$ & $\mathrm{S}_{\mathrm{SOP}^{+}} \mathrm{I}_{\mathrm{t}}$ \\
\hline Jun & 389 & 345 & 349 \\
\hline Jul & 295 & 295 & 843 \\
\hline Aug & 181 & 181 & 935 \\
\hline Sep & 190 & 190 & 1642 \\
\hline Oct & 290 & 290 & 1606 \\
\hline Nov & 190 & 190 & 1464 \\
\hline Dec & 326 & 326 & 1356 \\
\hline Jan & 240 & 240 & 1084 \\
\hline Feb & 201 & 201 & 843 \\
\hline Mar & 363 & 363 & 648 \\
\hline Apr & 364 & 288 & 294 \\
\hline May & 363 & 1 & 5 \\
\hline
\end{tabular}

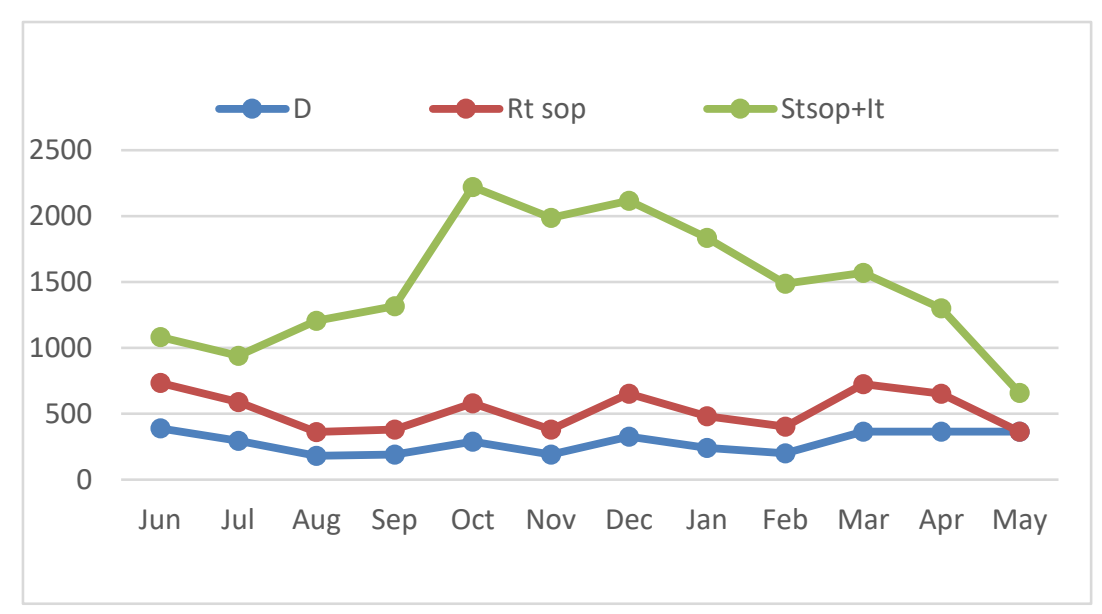

Figure 4 Graph of KRS SOP Operations 1995-96 Project Demands PD 
Performance Assessment of a Typical Semi Arid Water Reservoir for Different Kinds of Operations

Table 3.KRS Storages and releases as per actual operations 1995-1996 PD

\begin{tabular}{|c|c|c|c|c|c|}
\hline Months & $\begin{array}{c}\text { Storage at } \\
\text { the begin as per } \\
\text { Actual }\left(\mathbf{S}_{\mathbf{t} \text { act }}\right.\end{array}$ & $\begin{array}{c}\text { Inflow } \\
\text { During period t } \\
\left(\mathbf{I}_{\mathbf{t}}\right)\end{array}$ & $\begin{array}{c}\text { Evapora } \\
\mathbf{t i o n} \\
\text { During } \\
\mathbf{t}\left(\mathbf{E}_{\mathbf{t}}\right)\end{array}$ & $\begin{array}{c}\text { Project } \\
\text { Water } \\
\text { Demand } \\
\mathbf{d u r i n g} \mathbf{t} \\
\left(\mathbf{D}_{\mathbf{t}}\right)\end{array}$ & $\begin{array}{c}\text { Releases } \\
\text { as per } \\
\text { Actual in t } \\
\left(\mathbf{R t}_{\text {act }}\right)\end{array}$ \\
\hline Jun & 260 & 95 & 4 & 389 & 92 \\
\hline Jul & 883 & 843 & 14 & 295 & 206 \\
\hline Aug & 967 & 401 & 15 & 181 & 306 \\
\hline Sep & 1332 & 903 & 13 & 190 & 521 \\
\hline Oct & 1255 & 206 & 12 & 290 & 397 \\
\hline Nov & 1154 & 160 & 12 & 190 & 248 \\
\hline Dec & 996 & 94 & 11 & 326 & 240 \\
\hline Jan & 786 & 65 & 11 & 240 & 250 \\
\hline Feb & 581 & 10 & 10 & 201 & 207 \\
\hline Mar & 410 & 16 & 10 & 363 & 178 \\
\hline Apr & 291 & 19 & 6 & 364 & 181 \\
\hline May & 231 & 5 & 6 & 363 & 148 \\
\hline
\end{tabular}

Table 4: Derived from KRS Actual Operations 1995-96 PD

\begin{tabular}{|c|c|c|c|}
\hline Month & $\mathbf{D}_{\mathbf{t}}$ & $\mathbf{R}_{\mathbf{t} \text { - ACT }}$ & $\mathbf{S}_{\mathbf{t A C T}}+\mathbf{I}_{\mathbf{t}}$ \\
\hline Jun & 389 & 389 & 355 \\
\hline Jul & 295 & 295 & 1726 \\
\hline Aug & 181 & 181 & 1368 \\
\hline Sep & 190 & 190 & 2235 \\
\hline Oct & 290 & 290 & 1461 \\
\hline Nov & 190 & 190 & 1314 \\
\hline Dec & 326 & 326 & 1090 \\
\hline Jan & 240 & 240 & 851 \\
\hline Feb & 201 & 201 & 591 \\
\hline Mar & 363 & 363 & 426 \\
\hline Apr & 364 & 364 & 310 \\
\hline May & 363 & 269 & 236 \\
\hline
\end{tabular}

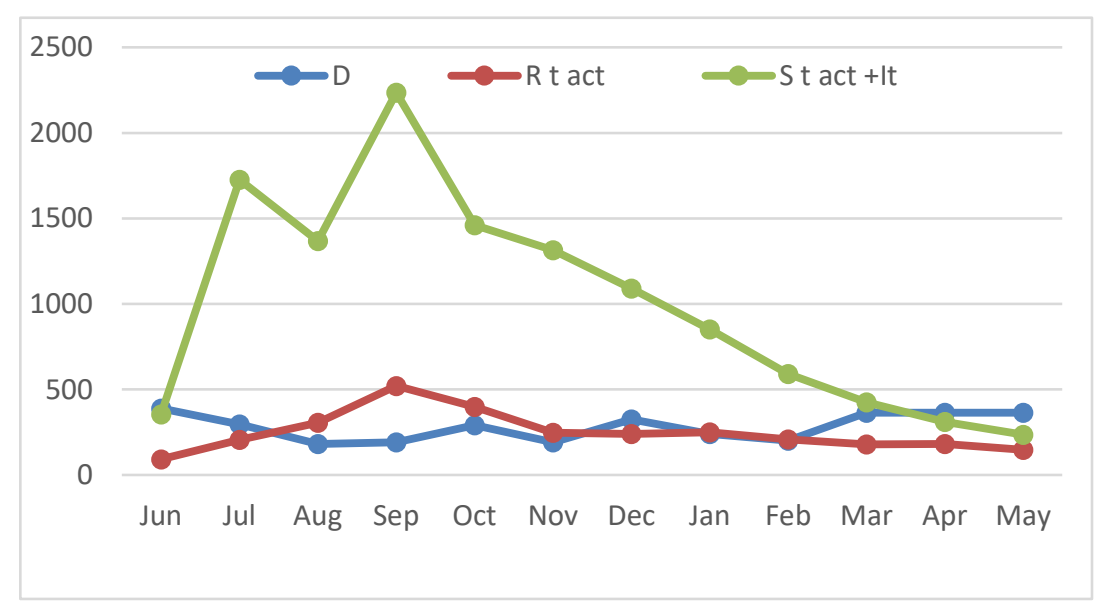

Figure 5 Graph of KRS Actual operations 1995-96 Project Demands 
KRS reservoir SOP operations are better in releasing water to required project based demands than actual operations. This can be observed in Fig.5 where the deviation in demands and water releases are heightened (x-axis is months in an irrigation year) as compared to Figure 4 , where in SOP is used for reservoir water release operations.

\section{THE SIMULATION OF HEDGING POLICY AND ITS COMPARISON WITH ACTUAL OPERATIONS FOR A SEMI-ARID KRS RESERVOIR.}

The simulation of Hedging Policy on KRS Reservoir is carried out with the following hedging algorithm.

$$
\begin{aligned}
& \mathrm{R}_{\mathrm{t}}=\mathrm{S}_{\mathrm{t}}+\mathrm{I}_{\mathrm{t}}, \mathrm{SP}_{\mathrm{t}}=0 \text { if } \mathrm{S}_{\mathrm{t}}+\mathrm{I}_{\mathrm{t}} \leq \mathrm{SWA} \ldots . \\
& \left.\mathrm{R}_{\mathrm{t}}=\mathrm{SWA}+\left(\mathrm{S}_{\mathrm{t}}+\mathrm{I}_{\mathrm{t}}-\mathrm{SWA}\right)[\mathrm{D}-\mathrm{SWA}) /(\mathrm{EWA}-\mathrm{SWA})\right] ; \mathrm{SP}_{\mathrm{t}}=0 \text { if } \mathrm{SWA}<\mathrm{S}_{\mathrm{t}}+\mathrm{I}_{\mathrm{t}}<\mathrm{EWA} \ldots \\
& \mathrm{R}_{\mathrm{t}}=\mathrm{D}, \mathrm{SP}_{\mathrm{t}}=0 \text { if EWA }<\mathrm{S}_{\mathrm{t}}+\mathrm{I}_{\mathrm{t}} \leq \mathrm{D}+\mathrm{C} \ldots . \\
& \mathrm{R}_{\mathrm{t}}=\mathrm{D}, \mathrm{SP}_{\mathrm{t}}=\mathrm{S}_{\mathrm{t}}+\mathrm{I}_{\mathrm{t}}-\mathrm{R}_{\mathrm{t}}-\mathrm{C}, \text { if } \mathrm{D}+\mathrm{C}<+\mathrm{I}_{\mathrm{t}} \ldots
\end{aligned}
$$

Where Eq.1, Eq.2,Eq.3,Eq.4 together constitute hedging rule adopted for KRS, $\mathrm{S}_{\mathrm{t}}=\mathrm{KRS}$ reservoir storage at time $t$ which is constrained between empty storage 0 and reservoir capacity of KRS, is $C_{\text {. } ; ~} I_{t}$ is the inflow into KRS reservoir at time $t ; R_{t}$ is the KRS reservoir release at time $t$, here $R_{t}$ denotes the KRS reservoir release used for demand $D$ i.e., $0 \leq R_{t} \leq D$; $S p_{t}$ is the KRS reservoir spill flow at time $t$, denoting wasteful release; $D$ is the project demand. The water shortage at any time period is defined as

$$
\mathrm{ST}_{\mathrm{t}}=|\mathrm{R}-\mathrm{D}| \text { if } \mathrm{R}<\mathrm{D} \text { and } \mathrm{ST}_{\mathrm{t}}=0 \text {, if } \mathrm{R}>\mathrm{D} \ldots \ldots
$$

The Reservoir storage at the next time $t+1$ is

$$
\mathrm{S}_{\mathrm{t}+1}=\mathrm{S}_{\mathrm{t}}+\mathrm{I}_{\mathrm{t}}-\mathrm{R}_{\mathrm{t}}-\mathrm{SP}_{\mathrm{t}} \ldots
$$

The Hedging is carried out for sixteen values of starting water availability SWA and ending water availability EWA .This is varied discreetly from $[0.2 \mathrm{D}+0.2 \mathrm{C}]$ to $[0.8 \mathrm{D}+0.8 \mathrm{C}]$.In each step, value of maximum shortage / Maximum Monthly Shortage (MST (obtained from $\mathrm{ST}_{\mathrm{t}}$ ) / MMS) and shortage ratio SR are obtained. Shortage Ratio is defined as

$$
\mathrm{SR}=\operatorname{Min}\left[\sum_{\mathrm{t}=1} \mathrm{~N}_{\mathrm{ST}_{\mathrm{t}}} / \mathrm{ND}\right] \ldots
$$

where ND is the demand in total number of operating time periods in the study horizon (one irrigation year here). The optimization criteria used after drawing contours of MST / MMS and SR is to minimize the MST and SR. The values of MMS and SR for year 1995-96 for sixteen points of [SWA, EWA] are given in TABLE 5 and TABLE 6 respectively.

Table 5. Table of maximum monthly shortage MMS values for 1995-96 PD

\begin{tabular}{|c|c|c|c|c|}
\hline $\begin{array}{c}\text { Y-Axis EWA } \\
\text { X-Axis SWA }\end{array}$ & {$[\mathbf{D + 0 . 2 C}]$} & {$[\mathbf{D + 0 . 4 C}]$} & {$[\mathbf{D + 0 . 6 C}]$} & {$[\mathbf{D + 0 . 8 C}]$} \\
\hline$[0.2 \mathrm{D}]$ & 253 & 232 & 238 & 252 \\
\hline$[0.4 \mathrm{D}]$ & 238 & 202 & 192 & 200 \\
\hline$[0.6 \mathrm{D}]$ & 265 & 144 & 138 & 142 \\
\hline$[0.8 \mathrm{D}]$ & 303 & 275 & 252 & 66 \\
\hline
\end{tabular}


Performance Assessment of a Typical Semi Arid Water Reservoir for Different Kinds of Operations

Table 6. Table of shortage ratios SR values for 1995-96 PD

\begin{tabular}{|c|c|c|c|c|}
\hline $\begin{array}{c}\text { Y Axis EWA } \\
\text { X Axis SWA }\end{array}$ & {$[\mathbf{D + 0 . 2 C}]$} & {$[\mathbf{D + 0 . 4 C}]$} & {$[\mathbf{D + 0 . 6 C}]$} & {$[\mathbf{D + 0 . 8 C}]$} \\
\hline$[0.2 \mathrm{D}]$ & 0.173 & 0.203 & 0.239 & 0.283 \\
\hline$[0.4 \mathrm{D}]$ & 0.149 & 0.171 & 0.199 & 0.235 \\
\hline$[0.6 \mathrm{D}]$ & 0.140 & 0.113 & 0.135 & 0.174 \\
\hline$[0.8 \mathrm{D}]$ & 0.127 & 0.128 & 0.134 & 0.067 \\
\hline
\end{tabular}

\section{OPTIMISING THE PARAMETERS OF HEDGING MAXIMUM MONTHLY SHORTAGES [MMS] AND SHORTAGE RATION [SR]}

Draw the isolines using Surfer 11 package for any package which supports drawing contours \}. The iso lines for MST and SR are drawn for various combinations of SWA and EWA for chosen irrigated year(s) time horizon. The optimal hedging rule for the KRS is obtained for recorded inflows (as well it should have been for future inflows also). The illustration of a contour diagram of the maximum monthly shortage for various combinations of SWA and EWA are given in Figure 3. In general, the maximum monthly shortage decreases with increasing SWA first and then increases with further increasing SWA.[11]

Fig. 6 can be used like this. Possible minimum monthly shortage contours are chosen as 130 $\mathrm{Mm}^{3}$ (A), $140 \mathrm{Mm}^{3}$ (B) or $160 \mathrm{Mm}^{3}(\mathrm{C})$. The SWA and EWA for A, B and C are obtained by drawing tangents and are for $\mathrm{A}(\mathrm{A} 1, \mathrm{~A} 2)\left[0.65 \mathrm{D}_{\mathrm{jm}}, \mathrm{D}_{\mathrm{jm}}+0.7 \mathrm{C}_{\mathrm{jm}}\right]=[253,572], \mathrm{B}(\mathrm{B} 1 . \mathrm{B} 2)$ $=\left(0.575 \mathrm{D}_{\mathrm{jm}}, \mathrm{D}_{\mathrm{jm}}+0.57 \mathrm{C}_{\mathrm{jm}}\right)=[224,538]$ and $\mathrm{C}(\mathrm{C} 1, \mathrm{C} 2)=\left(0.68 \mathrm{D}_{\mathrm{jm}}, \mathrm{D}+0.67 \mathrm{C}_{\mathrm{jm}}\right)=[264,567]$. Now by knowing probable inflows and existing storage in reservoir (physically available storage obtained by remote sensing of satellites or drones) and also keeping future periods requirements (based on remote sensing crop surveys) in mind, one can take these A,B,C as guiding values for initiating hedging operations at that intervention period (Julian month) of reservoir operations.

The iso-lines / contours for shortage ratio SR are drawn using Surfer 11 and are given in Figure 7. The Fig.7 can be used like this. Possible shortage ratio contours are chosen as $12 \%$ (C), $13 \%$ (A) or $14 \%$ (B) SR equivalent to $407 \mathrm{Mm}^{3}, 441 \mathrm{Mm} 3$ and $475 \mathrm{Mm}^{3}$ respectively. The SWA and EWA for $\mathrm{A}, \mathrm{B}$ and $\mathrm{C}$ are obtained by drawing tangents and are for $\mathrm{A}(\mathrm{A} 1, \mathrm{~A} 2)=$ $\left[0.58 \mathrm{D}_{\mathrm{jm}}, \mathrm{D}_{\mathrm{jm}}+0.37 \mathrm{C}_{\mathrm{jm}}\right]=[226,486], \mathrm{B}(\mathrm{B} 1, \mathrm{~B} 2)=\left[0.52 \mathrm{D}_{\mathrm{jm}}, \mathrm{D}_{\mathrm{jm}}+0.3 \mathrm{C}_{\mathrm{jm}}\right][202,468], \mathrm{C}(\mathrm{C} 1, \mathrm{C} 2)=$ $\left[0.68 \mathrm{D}_{\mathrm{jm}}, \mathrm{D}_{\mathrm{jm}}+0.7 \mathrm{C}_{\mathrm{jm}}\right]=[265,567]$.

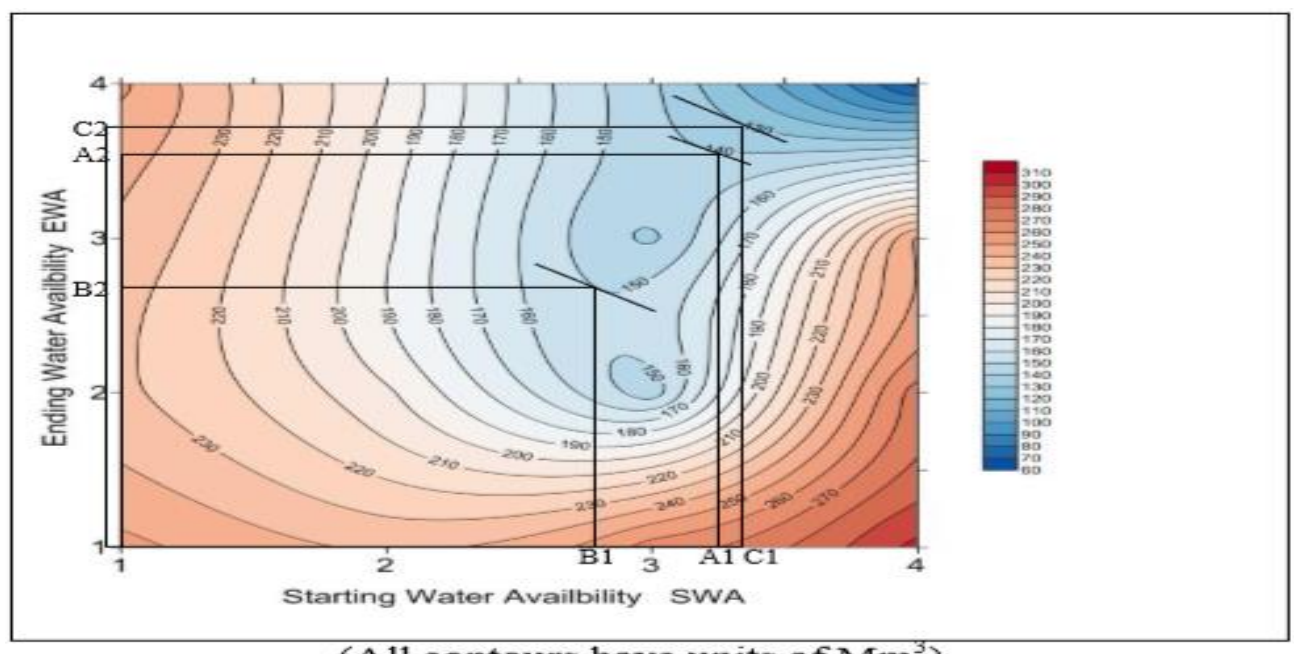

(A11 contours have units of $\mathrm{Mm}^{3}$ )

Figure 6 Hedging Performance characteristic MMS (Maximum Monthly Shortages) contours for KRS Project demands 1995-96 
If there are no modern methodologies adopted for knowing storages between two reservoir levels, as mentioned earlier by using remote sensing based methods, or stochastic forecasted values of storages, or total remaining storage capacity in the entire reservoir can also be used instead of julian month average capacity as availability.

Now by knowing probable inflows and existing storage in reservoir and also keeping future periods requirements in mind, one can take these $\mathrm{A}, \mathrm{B}, \mathrm{C}$ as guiding values for initiating hedging operations at that intervention period of reservoir operations. The possible minimum shortage ratios are chosen at $\mathrm{A}, \mathrm{B}$, and $\mathrm{C}$ by avoiding the islands of contours. The optimal SR of 13 percent (equivalent to $441 \mathrm{Mm}^{3}$ ) at A, having SWA of $226 \mathrm{Mm}^{3}$ and EWA $486 \mathrm{Mm}^{3}$ can be chosen.

Few other performance criteria of reservoir operations are obtained from each year of hedging simulation tables like volumetric reliability, time reliability, resilience, are defined as below and obtained for KRS reservoir operations in all the years (including 1995-96) which is shown in this paper elaborately, while hedging for project base crop demands.[11]

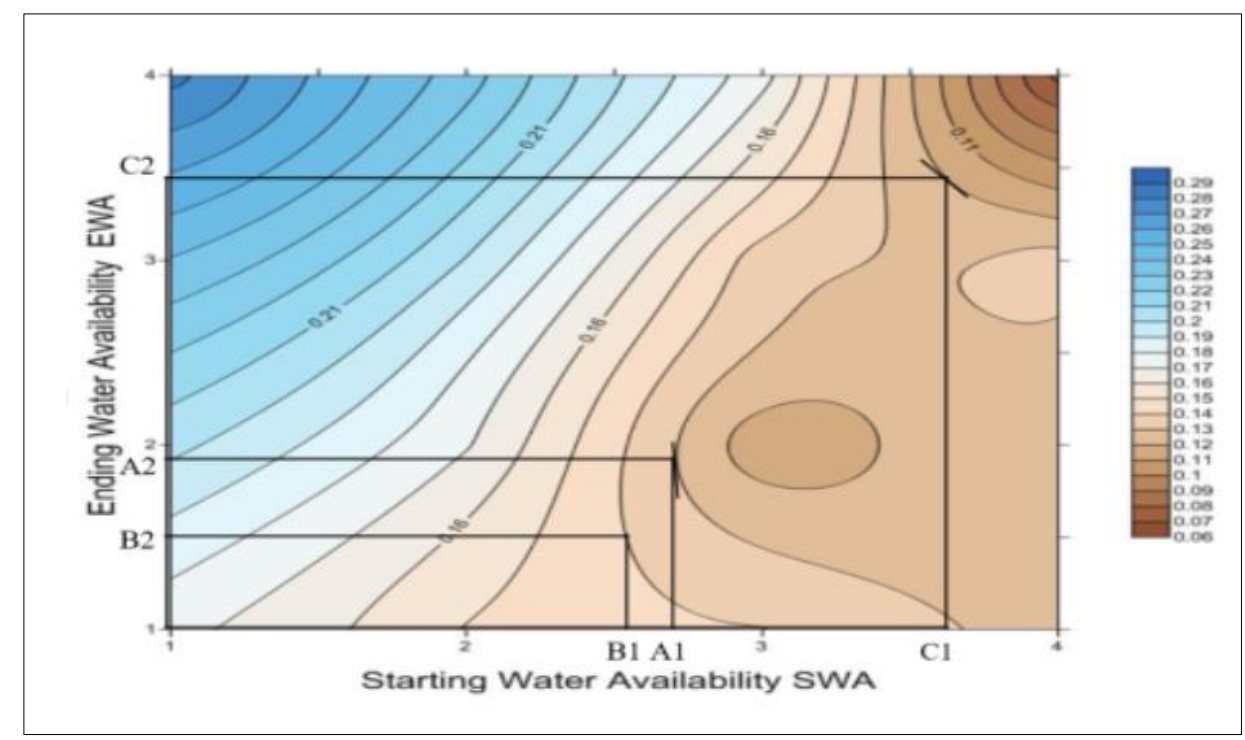

Figure 7 Hedging Performance characteristic SR (shortage ratio) contours for KRS Project demands 1995-96

Volumetric reliability of water supply: It is expressed as the ratio of the total water delivered to consumers $\left(\mathrm{S}_{\mathrm{i}}\right)$ to the total water demand $\left(\mathrm{D}_{\mathrm{i}}\right)$ in the time horizon (irrigation year)

$$
\mathrm{V}_{\mathrm{r}}=\sum_{\mathrm{i}=1} \mathrm{n}=\text { time steps }\left(\mathrm{S}_{\mathrm{i}}\right) / \sum_{\mathrm{i}=1} \mathrm{n}=\text { time steps } \mathrm{D}_{\mathrm{i}} \times 100
$$

Time reliability of water Supply:

$$
\mathrm{T}_{\mathrm{r}}=(1-\alpha)
$$

Where $\alpha=$ (total number of shortage periods / total number of operating periods)

Resilience defined as

$$
\mathrm{R}_{\mathrm{S}}=1 / \operatorname{Max} \mathrm{T}_{\mathrm{F}} \ldots . .
$$

where $T_{F}$ is the maximum duration of failure time (number of time steps) over a specified planning horizon (one year here). These reservoir performance indices for KRS are given in TABLE 7. The SWA and EWA at which each one of the performance parameters gets minimised or maximised can be adopted for reservoir operations. 
Performance Assessment of a Typical Semi Arid Water Reservoir for Different Kinds of Operations

Table 7 The reservoir performance characteristics $T_{r} V_{r}$ and $R_{S}$ for various values of SWA and EWA with SR and MMS are indicated for every month

\begin{tabular}{|c|c|c|c|c|c|c|}
\hline SWA & EWA & SR & MMS & Tr & Vr & Rs \\
\hline $0.2 \mathrm{D}$ & $\mathrm{D}+0.2 \mathrm{C}$ & 0.173 & 253 & 0.667 & 0.827 & 0.333 \\
\hline $0.4 \mathrm{D}$ & $\mathrm{D}+0.2 \mathrm{C}$ & 0.149 & 238 & 0.75 & 0.851 & 0.5 \\
\hline $0.6 \mathrm{D}$ & $\mathrm{D}+0.2 \mathrm{C}$ & 0.14 & 265 & 0.75 & 0.86 & 0.5 \\
\hline $0.8 \mathrm{D}$ & $\mathrm{D}+0.2 \mathrm{C}$ & 0.127 & 303 & 0.75 & 0.873 & 0.5 \\
\hline $0.2 \mathrm{D}$ & $\mathrm{D}+0.4 \mathrm{C}$ & 0.203 & 232 & 0.667 & 0.797 & 0.333 \\
\hline $0.4 \mathrm{D}$ & $\mathrm{D}+0.4 \mathrm{C}$ & 0.171 & 202 & 0.667 & 0.829 & 0.333 \\
\hline $0.6 \mathrm{D}$ & $\mathrm{D}+0.4 \mathrm{C}$ & 0.113 & 144 & 0.667 & 0.887 & 0.333 \\
\hline $0.8 \mathrm{D}$ & $\mathrm{D}+0.4 \mathrm{C}$ & 0.128 & 275 & 0.667 & 0.872 & 0.333 \\
\hline $0.2 \mathrm{D}$ & $\mathrm{D}+0.6 \mathrm{C}$ & 0.239 & 238 & 0.5 & 0.761 & 0.167 \\
\hline $0.4 \mathrm{D}$ & $\mathrm{D}+0.6 \mathrm{C}$ & 0.199 & 192 & 0.5 & 0.801 & 0.2 \\
\hline $0.6 \mathrm{D}$ & $\mathrm{D}+0.6 \mathrm{C}$ & 0.135 & 138 & 0.583 & 0.865 & 0.2 \\
\hline $0.8 \mathrm{D}$ & $\mathrm{D}+0.6 \mathrm{C}$ & 0.134 & 252 & 0.583 & 0.866 & 0.25 \\
\hline $0.2 \mathrm{D}$ & $\mathrm{D}+0.8 \mathrm{C}$ & 0.283 & 252 & 0.333 & 0.717 & 0.125 \\
\hline $0.4 \mathrm{D}$ & $\mathrm{D}+0.8 \mathrm{C}$ & 0.235 & 200 & 0.25 & 0.765 & 0.111 \\
\hline $0.6 \mathrm{D}$ & $\mathrm{D}+0.8 \mathrm{C}$ & 0.174 & 142 & 0.333 & 0.826 & 0.125 \\
\hline $0.8 \mathrm{D}$ & $\mathrm{D}+0.8 \mathrm{C}$ & 0.067 & 66 & 0.5833 & 0.796 & 0.2 \\
\hline
\end{tabular}

\section{CONCLUSIONS}

The following conclusions are formulated based on the study carried out on KRS reservoir.

1. The reservoirs whose operational policy is not prescribed specifically because of variance in decisions for water releases are taken socio-politically, there is a way to simulate the reservoir with a standard operating policy and compare performances graphically month wise.

2. The hedging rule based policy simulation is possible and leads to possibility of optimising parameters for reservoir operation like maximum monthly shortages or shortage ratio which are contemplated by decision makers while operating the reservoir month wise.

3. The choice of optimality/sub-optimality of one or few parameters (like volumetric reliability or resilience or time reliability etc) while hedging leads to flexible scenarios of water releases with suitable SWA and EWA, which can be updated in any month of the water year.

\section{ACKNOWLEDGEMENTS}

The field department data provided by Karnataka Neeravari Nigama Limited, Bangalore is acknowledged.

\section{REFERENCES}

[1] Yeh.W. W-G., "Reservoir management and operations models: A state-of-the-art review", Water Resour. Res., 21(12), 1985, 1797-1818.

[2] J. W. Labadie, "Optimal operation of multi reservoir systems: State-of-the-art review”, Journal of Water Resources Planning and Management, 130(2), 2004, 93-111

[3] Draper. Andrew J. and Lund. Jay R., "Optimal hedging and carry over storage", Journal of Water Resources Planning and Management, ASCE, 130:1 (83), 2004, 83-87 
[4] Wurbs. R. A, "Reservoir-system simulation and optimization models", J.Water Resources Planning and Management, ASCE, Vol 119, No 4.WWF and AWB, 1993, 455-472

[5] T.R. Neelakantan et al ,Review of Hedging Rules Applied to Reservoir Operation. / International Journal of Engineering and Technology (IJET) ISSN: 0975-4024 Vol 7 No 5 OctNov 2015 1571-1580

[6] Jiing-Yun You and Ximing Cai, Determining forecast and decision horizons for reservoir operations under hedging policies, Water Resources Research, Vol. 44, W11430, 2008, 1-14

[7] Jiing-Yun You and Ximing Cai, Hedging rule for reservoir operations: 1. A theoretical analysis Water Resources Research, Vol. 44, W01415, 2008,1-9

[8] Sham S Luthra Sant R Arora, Optimal Design of Single Reservoir System Using Release Policy, Water Resources Research 1976, Vol 12 No.4, 1-7

[9] Pramod R Bhave in "Reservoir Storage: Capacity Estimation and Operation in book "Water Resources Systems", New Delhi, Narosa Pulishing House, 2011.

[10] Government of India, Ministry of Water Resources, Cauvery Basin, Report by CWC-New Delhi and NRSC-Hyderabad, March 2014

[11] C J Jagadeesha, Development of Decision Support Systems for Reservoir Operation in a SemiArid Region Using Geoinformatics and Hedging Rule, doctoral dissertation, Karunya Institute of Technology and Sciences, Coimbatore, India ,2019 